\title{
The starvation-stress response of Vibrio (Listonella) anguillarum
}

\author{
David R. Nelson, ${ }^{1}$ Yola Sadlowski, ${ }^{1}$ Mitsuru Eguchi ${ }^{2}$ \\ and Staffan Kjelleberg ${ }^{3}$
}

Author for correspondence: David R. Nelson. Tel: +1 401874 2205. Fax: +1 4018747148.

e-mail: dnelson@uriacc.uri.edu

1 Department of Biochemistry, Microbiology and Molecular Genetics, University of Rhode Island, Kingston, RI 02881, USA

2 Department of Fisheries, Kinki University, Nakamachi, Nara 631 , Japan

3 School of Microbiology and Immunology, University of New South Wales, Sydney, NSW 2052, Australia
The starvation-stress response of Vibrio (Listonella) anguillarum was investigated and characterized with regard to changes in cell morphology and the ability of $V$. anguillarum to survive starvation, heat shock, exposure to $\mathrm{H}_{2} \mathrm{O}_{2}$ and exposure to ethanol. The ability of $\mathrm{V}$. anguillarum to survive exposure to the latter three stresses after initiation of starvation was also examined. Results of these experiments indicated that when starved for carbon, nitrogen and phosphorus, the c.f.u. of $\boldsymbol{V}$. anguillarum declined by about one order of magnitude over the first 5-7 d of starvation; starvation for an additional 3-4 weeks resulted in a gradual decline in c.f.u. by another order of magnitude. Examination of starved cells by electron microscopy revealed that while most cells formed spherical ultramicrocells during starvation, some of the cells elongated to form short spirals. While cross-protection against other stresses such as oxidative stress (exposure to $\mathrm{H}_{2} \mathrm{O}_{2}$ ) and exposure to ethanol developed, only a small degree of resistance to heat shock developed. Moreover, in all cases these resistances disappeared during prolonged starvation (usually $>5$ d). Additionally, the rate of protein synthesis per c.f.u., measured by [ ${ }^{35} 5$ ] methionine incorporation, declined during the initial $6 \mathrm{~h}$ of starvation and increased to over $\mathbf{7 0} \%$ of the rate measured in exponentially growing cells by $\mathbf{5} \mathrm{d}$ of starvation. It was concluded that the starvation-stress response of $\boldsymbol{V}$. anguillarum differs significantly from those starvation responses reported for other bacteria, including responses displayed by other Vibrio species.

Keywords: starvation, Vibrio (Listonella) anguillarum, stress response

\section{INTRODUCTION}

In natural environments bacteria and other microorganisms are constantly challenged by a variety of stressful conditions, which include nutrient limitation or starvation, as well as exposure to various forms of physical stress (e.g. temperature variation, osmotic shock, oxidative shock). Some bacteria escape these harsh conditions by differentiating into stress-resistant forms such as endospores or myxospores (Sonenshein, 1989; Zusman, 1984). Recent investigations have demonstrated that many non-differentiating bacteria also have the ability to withstand long periods of nutrient limitation and starvation (Matin et al., 1989; Morita, 1993; Östling et al., 1993; Spector \& Foster, 1993). Indeed, it has been suggested that in natural environments most micro-organisms face intermittent or prolonged periods of nutrient-limiting conditions and rarely, if ever, grow at rates approaching maximum
(Moriarty \& Bell, 1993; Morita, 1993). Recent investigations indicate that at the onset of starvation many bacteria exhibit the coordinated expression of protective mechanisms that allow the cells to survive exposure to multiple physical stresses (Givskov et al., 1994b; Jenkins et al., 1988; Östling et al., 1993). It is thought that the acquisition of such cross-protection during starvation is the result of the expression of starvation-stress proteins (Givskov et al., 1994a ; Hengge-Aronis, 1993). In contrast, Eguchi et al. (1996) suggest that marine oligotrophic bacteria grow at relatively constant rates over a very wide range of nutrient concentrations and are resistant to multiple physical stresses during both growth and starvation.

Vibrio species are generally found in the cultivable fraction of marine bacteria (Östling et al., 1993). While members of this genus proliferate in sites of high substrate concentration and reach high cell density, they 
are able to persist as free-living organisms in nutrientlimited waters for extended periods of time (Östling $e t$ al., 1993). Their coexistence with the dominant pool of oligotrophic bacteria in carbon-limited waters and their appearance in association with higher organisms suggest a successful life cycle of feast and famine. This is perhaps best documented for Vibrio (Listonella) anguillarum. This bacterium causes epizootics of vibriosis in a variety of marine fish and shellfish (Austin \& Austin, 1993; Bolinches et al., 1986; Bowser et al., 1981), but is able to persist under conditions of carbon starvation for at least four years (Hoff, 1989).

Here we examine the starvation-stress response of $V$. anguillarum with regard to the ability of this bacterium to adapt to and survive starvation and other stresses including heat shock, exposure to ethanol and exposure to hydrogen peroxide. We present evidence indicating that $V$. anguillarum exhibits a response to long-term starvation that is different from those responses described for copiotrophs such as Vibrio species strain S14 (Östling et al., 1993), Escherichia coli (Matin, 1991) and Pseudomonas putida (Givskov et al., 1994b). The latter three species of bacteria exhibit long-term starvation survival strategies that may be characterized as selfcontained. That is, cells exposed to starvation respond rapidly and in an ordered, sequential fashion to express genes and proteins that allow starved cells to become relatively less metabolically active and more resistant to a variety of potential environmental insults (Givskov $e t$ al., 1994b; Matin, 1991; Östling et al., 1993). In contrast to this response, our data suggest that $V$. anguillarum cells exhibit a somewhat different strategy towards starvation. This alternative strategy does not include a long-term reduction in metabolic activity and long-term stress cross-protection; rather $V$. anguillarum cells first lose and later regain metabolic activity during starvation. Additionally, $V$. anguillarum cells exhibit only a limited set of starvation-acquired cross-protections, which are lost as starved cells regain metabolic activity.

\section{METHODS}

Bacterial strains and culture conditions. V. anguillarum 2129 was isolated from a diseased fish. Cultures of $V$. anguillarum were routinely grown and maintained in Luria-Bertani broth (Maniatis et al., 1982) plus $2 \% \mathrm{NaCl}(\mathrm{LB} 20)$ at $25^{\circ} \mathrm{C}$ with shaking or on LB20 agar plates also incubated at $25^{\circ} \mathrm{C}$. Typically for experiments, aliquots from overnight cultures grown in LB20 at $25^{\circ} \mathrm{C}$ were transferred to flasks of marine minimal medium (3M) (Neidhardt et al., 1974) and grown to mid-exponential phase to stationary phase $\left(10^{7}-10^{9}\right.$ c.f.u. $\left.\mathrm{ml}^{-1}\right)$. Growth was measured as $\mathrm{OD}_{550}$.

Starvation and stress-challenge protocols. $V$. anguillarum cells were starved for carbon $(\mathrm{C})$, nitrogen $(\mathrm{N})$ or phosphorus (P), or all three simultaneously (CNP). Cells to be starved were grown to the desired density $\left(10^{7}-10^{9}\right.$ c.f.u. $\left.\mathrm{ml}^{-1}\right)$, harvested by centrifugation $\left(9000 \mathrm{~g}, 10 \mathrm{~min}, 25^{\circ} \mathrm{C}\right)$, and washed and resuspended in the appropriate starvation broth. Starvation for carbon was performed in $3 \mathrm{M}$ minus glucose. Starvation for nitrogen was performed in $3 \mathrm{M}$ minus $\mathrm{NH}_{4} \mathrm{Cl}$. Starvation for phosphorus was performed in $3 \mathrm{M}$ minus potassium phosphate. Starvation for CNP was performed by incubating the cells in either $3 \mathrm{M}$ without added glucose, $\mathrm{NH}_{4} \mathrm{Cl}$ and potassium phosphate or in nine salts solution (NSS) (Marden et al., 1985). All starvation experiments were carried out at $25-28^{\circ} \mathrm{C}$. To determine the effects of starvation on the viability of $V$. anguillarum cells, samples were withdrawn at various intervals after the initiation of starvation and the c.f.u. determined by dilution and plating onto LB20 agar or, in some cases, VNSS agar (Nyström \& Kjelleberg, 1987). All plate counts were performed in triplicate.

Cells to be heat shocked were harvested by centrifugation, washed twice (in either $3 \mathrm{M}$ or NSS), and resuspended in fresh $3 \mathrm{M}$ broth or in NSS at $25^{\circ} \mathrm{C}$. Aliquots were withdrawn from the $3 \mathrm{M}$ cultures after $5 \mathrm{~min}$ of equilibration or from the NSS starvation cultures at the times indicated in the text and transferred to a $42{ }^{\circ} \mathrm{C}$ water bath for heat shock. To determine the effects of heat shock on the viability of $V$. anguillarum cells, samples were withdrawn $60 \mathrm{~min}$ after transfer to $42{ }^{\circ} \mathrm{C}$ and the c.f.u. determined by serial dilution and plating onto LB20 agar. All plating was carried out in triplicate.

Cells to be challenged by exposure to $\mathrm{H}_{2} \mathrm{O}_{2}$ were harvested by centrifugation, washed and resuspended in $3 \mathrm{M}$ broth or NSS as described above. Aliquots were withdrawn and $\mathrm{H}_{2} \mathrm{O}_{2}$ added to a final concentration of $2 \mathrm{mM}$. Samples were withdrawn 15 min after the addition of $\mathrm{H}_{2} \mathrm{O}_{2}$ and the c.f.u. determined by serial dilution and plating onto LB20 agar.

Cells to be challenged by exposure to ethanol were harvested, washed and resuspended in $3 \mathrm{M}$ or NSS as described above. Aliquots were withdrawn and ethanol added to a final concentration of $12 \%(\mathrm{v} / \mathrm{v})$. Samples were withdrawn $15 \mathrm{~min}$ after the addition of ethanol and the c.f.u. determined by serial dilution and plating onto LB20 agar.

Electron microscopy. $V$. anguillarum cells were fixed by the addition of $50 \%$ glutaraldehyde (EM grade; Electron Microscopy Sciences) to a final concentration of $1 \%(\mathrm{w} / \mathrm{v})$. For negative stains, one drop of culture was placed onto a 200 mesh C-coated/collodion grid. After $10 \mathrm{~min}$, the drop was removed and the grid was negatively stained with $1 \%$ ammonium molybdate. For thin sections, a $5 \mathrm{ml}$ aliquot of each culture was centrifuged at $9000 \mathrm{~g}$ for $30 \mathrm{~min}$ at $5^{\circ} \mathrm{C}$. The cell pellet was gently disrupted and enrobed in molten $\left(44^{\circ} \mathrm{C}\right)$ $1.5 \%$ purified agar in $0.1 \mathrm{M}$ sodium cacodylate buffer ( $\mathrm{pH} 7 \cdot 2$ ). The excess agar was trimmed away from around the cell pellet fractions and these small agar cubes were placed in $3 \mathrm{ml}$ vials containing $3 \%$ glutaraldehyde in $0.1 \mathrm{M}$ sodium cacodylate buffer overnight at $4{ }^{\circ} \mathrm{C}$. The samples were washed three times ( $30 \mathrm{~min}$ each wash) with buffer, fixed with $1 \%$ osmium tetroxide in buffer for $3 \mathrm{~h}$, and dehydrated in a graded ethanol series to $95 \%$ ethanol. All washes and ethanol dehydrations were carried out at $4{ }^{\circ} \mathrm{C}$. The samples were allowed to warm to room temperature and then changed four times with absolute ethanol for $14 \mathrm{~min}$ each. After two additional changes with propylene oxide, the samples were embedded in Spurr's epoxy resin and thin-sectioned with a diamond knife on a DuPont/Sorval MT2-B ultramicrotome. The sections were stained with $2 \%$ uranyl acetate in $50 \%$ methanol followed by lead citrate. The negative stains and thin sections were examined and photographed with a JEOL $1200 \mathrm{EX}$ transmission electron microscope operating at $80 \mathrm{kV}$.

Radioactive labelling of cells. Concurrent with sampling for viability measurements, $1 \mathrm{ml}$ cell suspension in either $3 \mathrm{M}$ (exponentially growing cells) or NSS (starved cells) was labelled with $\left.10 \mu \mathrm{Ci}\left(3.7 \times 10^{5} \mathrm{~Bq}\right){ }^{35} \mathrm{~S}\right]$ methionine (Dupont, NEN Research Products; sp. act. $>600 \mathrm{Ci} \mathrm{mmol}^{-1}$ ) for $30 \mathrm{~min}$ at $25^{\circ} \mathrm{C}$. When the labelling period was complete, the cells were centrifuged $(15000 \mathrm{~g}, 2 \mathrm{~min})$, washed twice in NSS, and 
resuspended in $100 \mu \mathrm{l} 10 \mathrm{mM}$ Tris buffer ( $\mathrm{pH} 7 \cdot 2$ ), and frozen for storage. Incorporated radioactivity was determined by scintillation counting of TCA-precipitated protein pellets (Nelson \& Zusman, 1983).

Gel electrophoresis and autoradiogaphy. One-dimensional SDS-PAGE was performed as described by Laemmli (1970) using $5 \%$ stacking gels and $10 \%$ separating gels. Autoradiography was performed as previously described (Nelson \& Killeen, 1986). Equal volumes of labelled cell suspensions were loaded onto each lane.

\section{RESULTS}

\section{Changes in cell viability and morphology during $C$ or CNP starvation}

The response of $V$. anguillarum cells to starvation for $C$ was compared to simultaneous starvation for CNP. For periods of starvation up to at least $28 \mathrm{~d}(672 \mathrm{~h})$, the survival of cells (as measured by c.f.u.) starved for C paralleled that of cells starved for CNP (Fig. 1a). Typically, the drop in c.f.u. over a 4 week starvation was slightly greater than two orders of magnitude. The decline in viable cells was usually biphasic, with the most rapid drop in c.f.u. occurring during the first 72-168 h (3-7 d) of starvation. The decline in c.f.u. slowed after that time. Additionally, over the first 6-24 h of starvation there was often a two- to threefold increase in c.f.u. This general pattern of cell viability was reproducible in starvation experiments with initial cell densities ranging from $10^{7}$ to $10^{9}$ c.f.u. $\mathrm{ml}^{-1}$ (data not shown).

The effects of potential oxygen-limiting conditions and the composition of the recovery plating medium on starvation survival were also examined (Fig. 1b). Cells were starved for CNP in either shaking or standing cultures. Samples were withdrawn at intervals and plated onto either a high-concentration nutrient agar (LB20) or a lower-concentration nutrient agar (VNSS). Regardless of the starvation conditions (shaken or still) and the recovery growth conditions (high or low nutrient), no differences in c.f.u. were detected. Further, an examination of $\mathrm{pH}$ during starvation revealed that the $\mathrm{pH}$ decreased by only 0.3 unit from $\mathrm{pH} 7.5$ during the 4 week starvation.

The morphology of cells starved for CNP was examined by transmission electron microscopy of both negatively stained cells and thin sections of cells (Fig. 2). During the first $24 \mathrm{~h}$ of starvation, some changes from exponentialphase cells to starved cells were observed. The most noticeable differences between exponential-phase cells (Fig. 2a, b; mean diameter \pm SD of 25 cells was $0.54 \pm 0.05 \mu \mathrm{m}$ ) and cells starved for $24 \mathrm{~h}$ (Fig. $2 \mathrm{c}, \mathrm{d}$; mean diameter $0.46 \pm 0.06 \mu \mathrm{m}$ ) were a decrease in the observed diameter of about $15 \%$ and the appearance of some helical cells. There were few differences between cells starved for $48 \mathrm{~h}$ (not shown) and cells starved for $24 \mathrm{~h}$. By $168 \mathrm{~h}$ (Fig. 2e, f) of starvation, there were a number of clearly observed changes in the morphology of the cells. Most cells had become rounded, contained less internally staining material and probably lost integrity. These cells were probably dead. From numerous observations by both electron microscopy and phase-contrast microscopy, it appeared that about $10 \%$ of the cells appeared to have elongated into curved or helical filaments. Cells that retained an intact cell envelope had a mean diameter about $78 \%$ $(0.42 \pm 0.06 \mu \mathrm{m})$ of that observed in exponential-phase cells. Observations by phase-contrast microscopy indicated that most cells lost motility between 6 and $24 \mathrm{~h}$ after the initiation of starvation. However, a small number of motile cells could be observed even after prolonged periods of starvation.

\section{Changes in cell viability during starvation for $\mathbf{N}$ or $\mathbf{P}$}

The effects of starvation for $\mathrm{N}$ or $\mathrm{P}$ on $\mathrm{V}$. anguillarum viability were examined. Typical cell survival curves for $V$. anguillarum starved for $\mathrm{N}$ or $\mathrm{P}$ (for periods up to

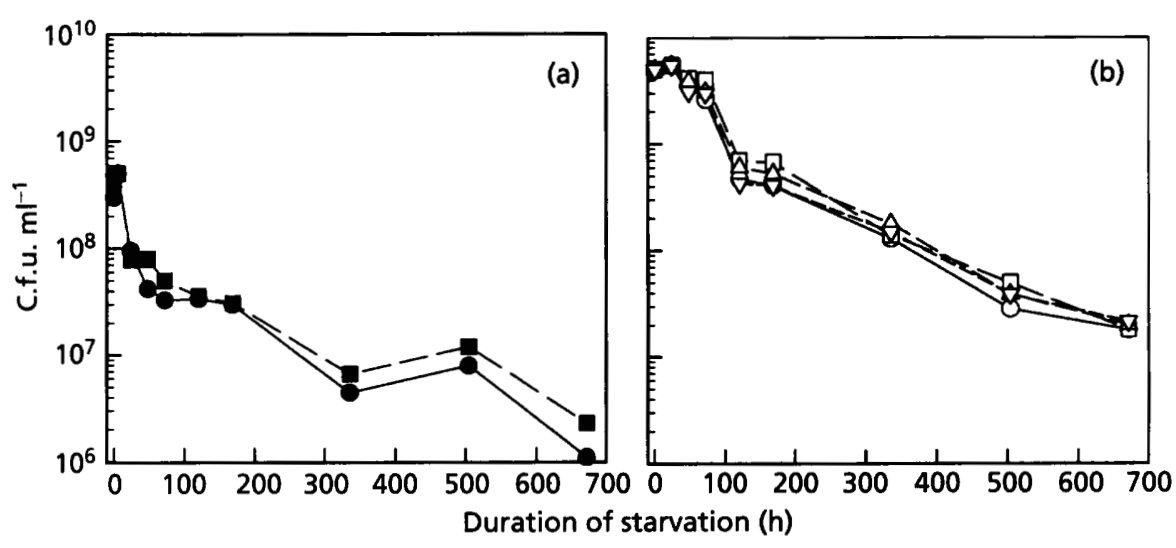

Fig. 1. Survival of $V$. anguillarum under conditions of starvation for $C$ or CNP. (a) Cells starved for $C(O)$ or CNP ( $\square$ ) were compared. Cells were grown to $\sim 10^{8}$ c.f.u. $\mathrm{ml}^{-1}$ in Marine Minimal Medium $(3 \mathrm{M})$ at $25^{\circ} \mathrm{C}$, washed, resuspended in the appropriate starvation medium and incubated at $25^{\circ} \mathrm{C}$. Samples were withdrawn at indicated intervals and the c.f.u. determined by serial dilution and plating on LB20. (b) Cells starved for CNP were compared for survival during incubation in shaken cultures $(0, \Delta)$ or stationary cultures $(\square, \nabla)$. Cultures were prepared as described above and c.f.u. determined by dilution and plating on either LB2O $(O, \square)$ or on VNSS $(\Delta, \nabla)$. 

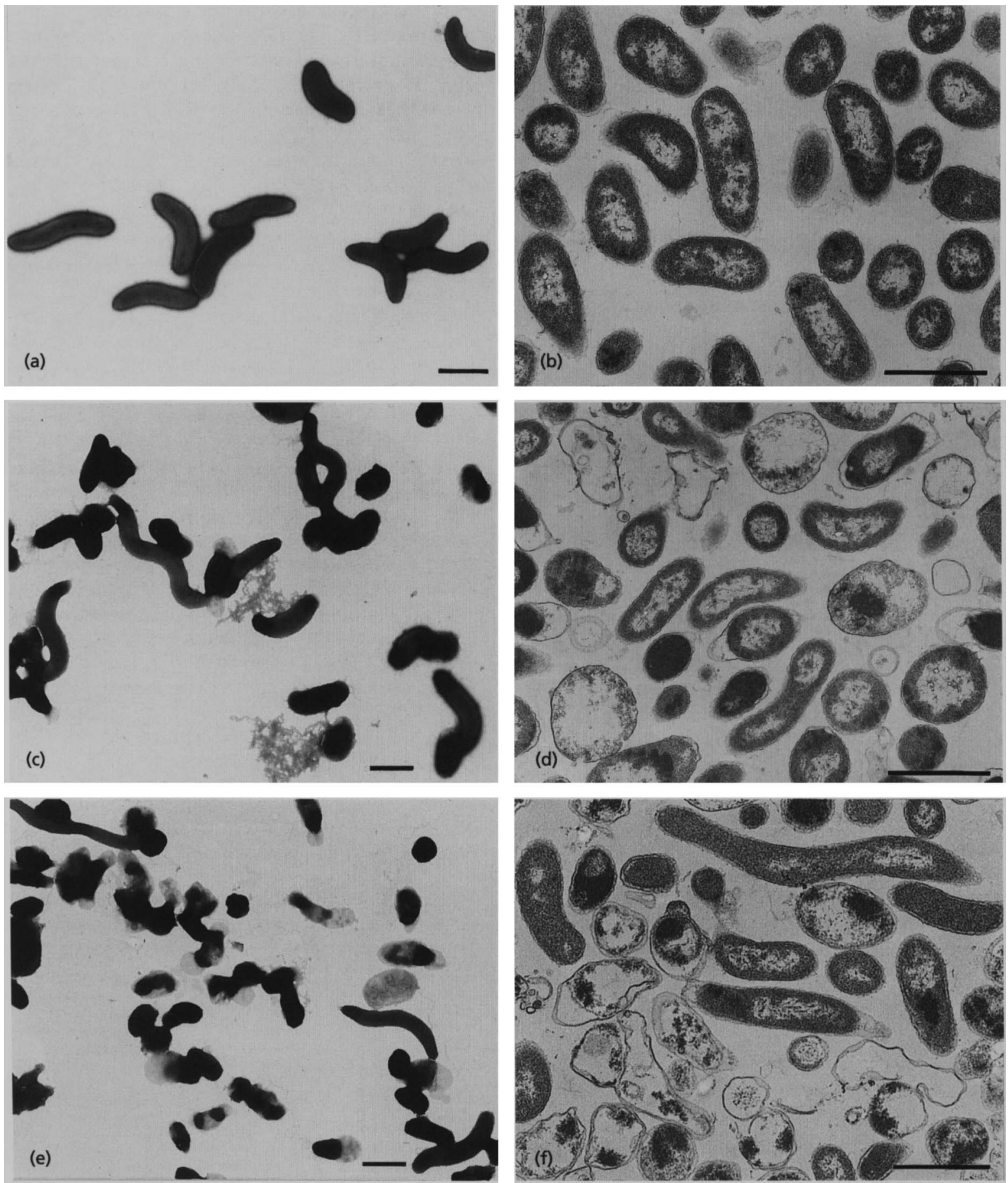

Fig. 2. Electron micrographs showing the morphology of growing and starved ( $24 \mathrm{~h}$ and $168 \mathrm{~h}$ ) $\mathrm{V}$. anguillarum cells. Cells were grown in $3 \mathrm{M}(\mathrm{a}, \mathrm{b})$ or allowed to starve for $C, N$ and $P$ for $24 \mathrm{~h}(c, d)$ and $168 \mathrm{~h}(e, f)$. Panels a, $c$ and e show cells negatively stained with uranyl acetate. Panels $b, d$, and f show cells thin-sectioned and stained with uranyl acetate and lead citrate. Bars, $1 \mu \mathrm{m}$.

$840 \mathrm{~h}$ ) are shown in Fig. 3. A c.f.u. survival curve for CNP starvation is included for comparison. During the first $24 \mathrm{~h}$ of starvation the c.f.u. increased in both $\mathrm{N}$ - and P-starved cultures (three- and ninefold, respectively). Subsequently, the c.f.u. for both N- or P-starved cells decreased. The c.f.u. of $\mathrm{N}$-starved cells decreased by $1 \cdot 1$ orders of magnitude (12-fold) between 24 and $120 \mathrm{~h}$. This is about the same decrease as observed in CNPstarved cells between 0 and $120 \mathrm{~h}$ of starvation. Between 120 and $840 \mathrm{~h}$ ( 5 and $35 \mathrm{~d}$ ) of $\mathrm{N}$ starvation the c.f.u. declined by an additional $0.6 \mathrm{log}$. The c.f.u. of P-starved cells decreased by almost three orders of magnitude 


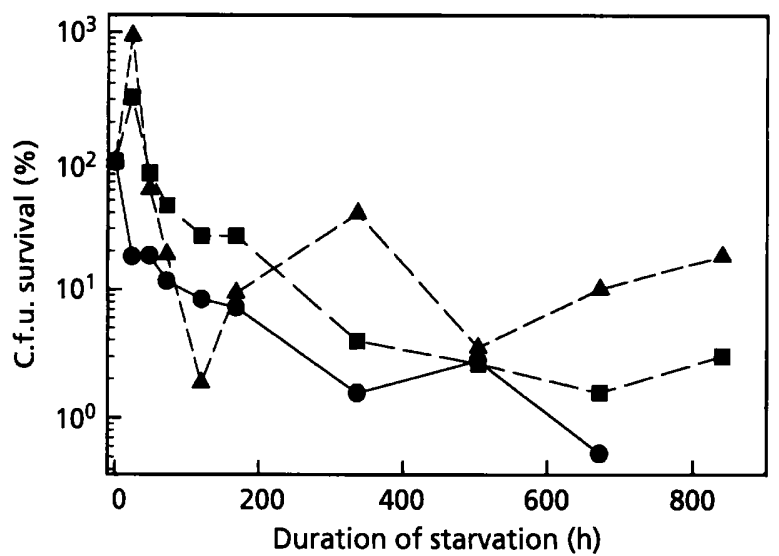

Fig. 3. Survival of $V$. anguillarum starved of CNP (O), $N(\square)$ and $P(\Delta)$. Cells were grown to $\sim 10^{8}$ c.f.u. $\mathrm{ml}^{-1}$ in $3 \mathrm{M}$ at $25^{\circ} \mathrm{C}$, washed, resuspended in the appropriate starvation medium and incubated at $25^{\circ} \mathrm{C}$. Samples were withdrawn at indicated intervals and the c.f.u. determined by plating on LB20.

between 24 and $120 \mathrm{~h}$. Between 120 and $840 \mathrm{~h}$ of $\mathrm{P}$ starvation, the c.f.u. appeared to oscillate with a periodicity of $300-500 \mathrm{~h}$ between peaks in c.f.u. It is interesting to note that the long-term ( $>168 \mathrm{~h}$ ) c.f.u. survival of $V$. anguillarum was not dependent upon the depleted nutrient.

\section{Starvation-induced cross-protection in V. anguillarum}

Recently it has been reported that a number of different bacteria develop a multiple stress-resistant state when the organism is starved of nutrients (Givskov et al., 1994b; Jenkins et al., 1988; Matin, 1991; Spector \& Foster, 1993). We sought to determine whether this was the case for $V$. anguillarum. Growing cells (midexponential phase in $3 \mathrm{M}$ ) and cells starved in NSS for periods of up to $168 \mathrm{~h}$ were challenged with heat shock $\left(42{ }^{\circ} \mathrm{C}\right), \mathrm{H}_{2} \mathrm{O}_{2}(2 \mathrm{mM})$ or ethanol $(12 \%)$ (see Fig. 4). The sensitivity of the cells to each of these treatments was determined by the time-dependent reduction in c.f.u. The data presented illustrate representative experiments from a minimum of three trials for each stress. The general survival patterns described are reproducible. As shown in Fig. 4(a), exponentially growing cells $(t$ $=-1 \mathrm{~h}$ ) declined by more than two orders of magnitude when exposed to a $42{ }^{\circ} \mathrm{C}$ heat shock for $60 \mathrm{~min}$. Cells starved for up to $120 \mathrm{~h}$ were somewhat more resistant than growing cells. However, cells starved for $168 \mathrm{~h}$ lost the small amount of resistance gained during shorter periods of starvation and were slightly more sensitive to heat shock than growing cells.

A somewhat different pattern of starvation-induced cross-protection was observed for cells challenged with $\mathrm{H}_{2} \mathrm{O}_{2}$ (2 mM, 15 min; Fig. 4b). Growing cells $(t=-1 \mathrm{~h})$ were extremely sensitive to oxidative stress, exhibiting a decline in c.f.u. of almost four orders of magnitude during a 15 min exposure to $\mathrm{H}_{2} \mathrm{O}_{2}$. Cells washed free of growth medium and resuspended in NSS rapidly gained resistance to $\mathrm{H}_{2} \mathrm{O}_{2}$. Resistance peaked by $24 \mathrm{~h}$ of starvation, with about $50 \%$ of the starved cells surviving $\mathrm{H}_{2} \mathrm{O}_{2}$ exposure. Oxidative-stress resistance exhibited a broad plateau between $24 \mathrm{~h}$ and $96 \mathrm{~h}$ of starvation. After $96 \mathrm{~h}$, resistance declined and by $168 \mathrm{~h}$ of starvation, the cells were almost as sensitive to oxidative stress as growing cells.

A third variation of starvation-cross protection was seen for starvation-acquired resistance to ethanol stress. Growing cells exposed to $12 \%$ ethanol for $15 \mathrm{~min}$ declined by about two orders of magnitude. However, cells washed free of $3 \mathrm{M}$ broth and resuspended in NSS were extremely sensitive to ethanol. Typically, survival was only $10^{-5}$ of the input cell population. By $24 \mathrm{~h}$ of starvation, $V$. anguillarum cells exhibited about the same sensitivity to ethanol as growing cells, with about $1 \%$ of the input cells surviving the ethanol shock. Resistance increased about tenfold between $24 \mathrm{~h}$ and $72 \mathrm{~h}$ of starvation. Ethanol resistance declined after

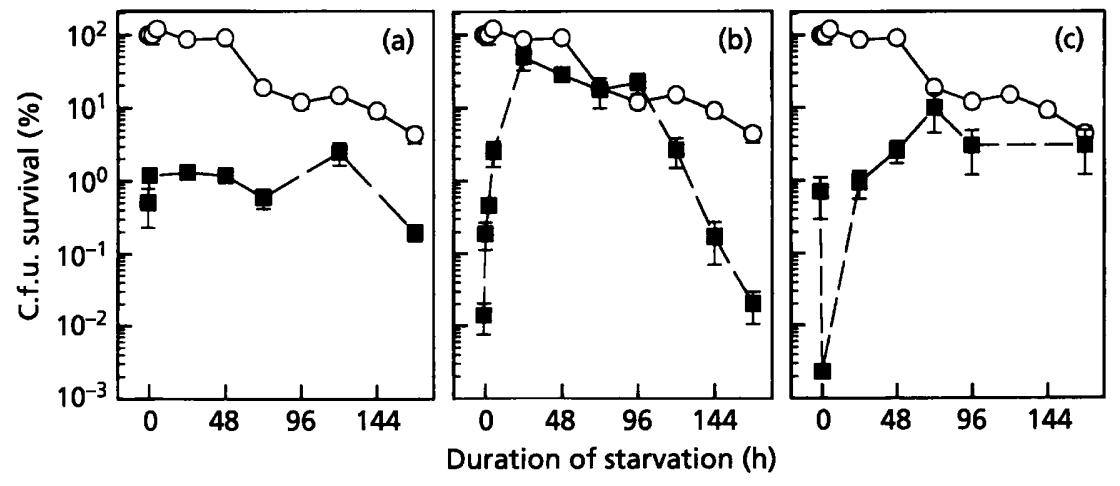

Fig. 4. Effects of starvation on survival of $V$. anguillarum cells exposed to (a) heat shock at $42{ }^{\circ} \mathrm{C} ;\left(\right.$ (b) $2 \mathrm{mM} \mathrm{H}_{2} \mathrm{O}_{2} ;$ and (c) $12 \%$ ethanol. Cells were grown in $3 \mathrm{M}$ to $\sim 10^{8}$ c.f.u. $\mathrm{ml}^{-1}$ at $25^{\circ} \mathrm{C}$, washed and resuspended in NSS starvation medium (minus CNP) and incubated at $25^{\circ} \mathrm{C}$. Aliquots were withdrawn periodically to determine starvation survival (O) and to determine stress resistance $(\square)$ by challenge with the appropriate stress as described in Methods. C.f.u. were determined by serial dilution and plating on LB20. Each data point is the mean of triplicate samples. Error bars indicate the standard deviation. The data shown are representative experiments from a minimum of three trials for each stress. 
Table 1. Relative rates of $\left.{ }^{35} \mathrm{~S}\right]$ methionine incorporation by $V$. anguillarum starved for CNP

Cells were labelled and radioactivity determined as described in Methods. The relative rates of $\left[{ }^{35} \mathrm{~S}\right]$ methionine incorporation were determined by dividing the value of the incorporated c.p.m. per $10^{8}$ c.f.u. for any time point by the value determined for exponentially growing cells. The value for $\left[{ }^{35} \mathrm{~S}\right]$ methionine incorporation in exponentially growing cells was $7 \cdot 5 \times 10^{4}$ c.p.m. per $10^{8}$ c.f.u.

\begin{tabular}{|cc|}
\hline Duration of starvation $(\mathbf{h})$ & $\begin{array}{c}\text { Relative rate of } \\
{\left[{ }^{35} \text { S }\right] \text { methionine }} \\
\text { incorporation }\end{array}$ \\
\hline Exponentially growing cells & $1 \cdot 00$ \\
Starved cells & \\
0 & $0 \cdot 58$ \\
1 & $0 \cdot 47$ \\
6 & $0 \cdot 17$ \\
24 & $0 \cdot 28$ \\
48 & $0 \cdot 31$ \\
72 & $0 \cdot 46$ \\
120 & $0 \cdot 70$ \\
168 & $0 \cdot 73$ \\
\hline
\end{tabular}

$72 \mathrm{~h}$, and by $168 \mathrm{~h}$ of starvation the starved cells were almost as sensitive to ethanol as growing cells.

\section{Protein synthesis by starved $\boldsymbol{V}$. anguillarum cells}

The appearance of helical cells and the loss of starvationinduced stress cross-protection during prolonged $(>24 \mathrm{~h}$ ) starvation suggested that $V$. anguillarum cells were not dormant. To examine this more directly, cells were labelled with $\left[{ }^{35} \mathrm{~S}\right]$ methionine during exponential growth and at various times during starvation for CNP (in NSS). The relative rates of $\left[{ }^{35} \mathrm{~S}\right]$ methionine incorporation into TCA-precipitable material were determined and are shown in Table 1 . The data reveal that during the first $6 \mathrm{~h}$ of starvation the rate of incorporation per c.f.u. fell by over $80 \%$ from that of exponentialphase cells. The rate of incorporation per c.f.u. increased after that time, and by $168 \mathrm{~h}$ the rate was almost $75 \%$ of that observed in exponential-phase cells. Examination of protein expression in growing and starved cells labelled with $\left[{ }^{35}\right.$ S $]$ methionine by SDS-PAGE, autoradiography, and densitometry (Fig. 5) revealed a similarity with the data presented in Table 1 . Both the number of proteins expressed and the overall level of protein expression fell rapidly from 37 bands detected in growing cells (and $t=0 \mathrm{~h}$ starved cells) to a minimum of 17 detectable bands with a total density of $\sim 6 \%$ that of growing cells in cells starved for $24 \mathrm{~h}$. Both the complexity and the levels of protein expression began to increase by $48 \mathrm{~h}$ of starvation. Twenty-three protein bands with a total density of $7 \%$ that of growing cells (and $t=0 \mathrm{~h}$ cells) were detected in cells labelled after $48 \mathrm{~h}$ of starvation. By $168 \mathrm{~h}$ of starvation, the number of detectable bands had increased to 31 with a total density of about $25 \%$ that of growing cells.

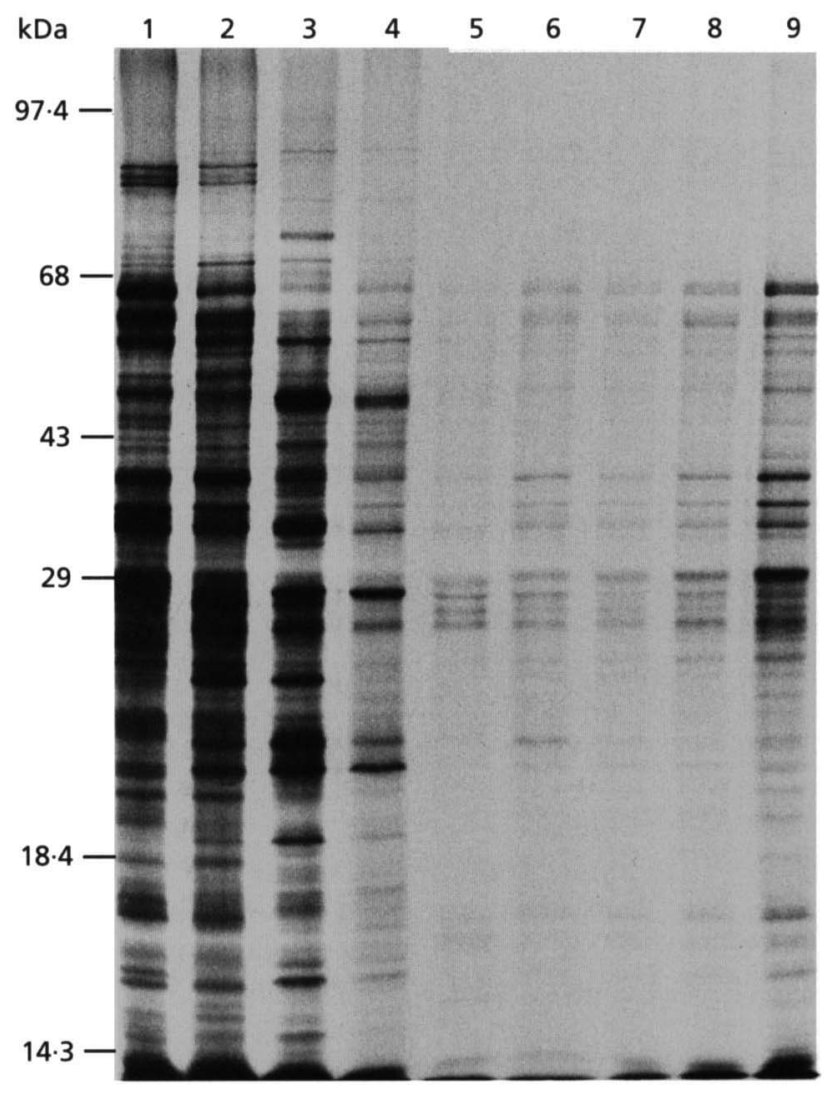

Fig. 5. Autoradiogram of $\left[{ }^{35} \mathrm{~S}\right]$ methionine-labelled proteins from growing and starved $V$. anguillarum cells. Cells were grown in $3 \mathrm{M}$ broth and starved in NSS broth as described in Methods. Aliquots were taken and labelled with ${ }^{35} \mathrm{~S}$ ] methionine during growth in $3 \mathrm{M}$ broth (lane 1) and at the following times during starvation: lane 1, exponentially growing cells; lane $2,0 \mathrm{~h}$; lane $3,1 \mathrm{~h}$; lane $4,6 \mathrm{~h}$; lane $5,24 \mathrm{~h}$ lane 6, $48 \mathrm{~h}$; lane $7,72 \mathrm{~h}$; lane $8,120 \mathrm{~h}$; lane 9, $168 \mathrm{~h}$. Molecular mass standards are indicated in $\mathrm{kDa}$.

\section{DISCUSSION}

It is clear that marine and other bacteria have evolved mechanisms to survive the stress of starvation until nutrients again become available to support the growth of cells. The starvation-survival strategies employed by bacteria include at least the adaptive processes of oligotrophy, spore and cyst formation, and copiotrophy (Östling et al., 1993; Poindexter, 1981; Rozak \& Colwell, 1987; Schut et al., 1993). Copiotrophic bacteria exhibit relatively rapid growth rates under conditions of abundant nutrients and survive starvation without the development of spores or cysts (Nyström et al., 1990). Such organisms include well-characterized 'non-differentiating' bacteria such as E. coli, P. putida and Vibrio sp. S14. When starved, particularly of carbon or multiple nutrients, these bacteria rapidly form starvation-stressresistant cells which are generally characterized by their small, coccoid shape (ultramicrocells), their rapid acquisition of cross-protection against a variety of stresses and their instantaneous response to added nutrients (Givskov et al., 1994a,b; Holmquist \& 
Kjelleberg, 1993; Matin, 1991; Nyström et al., 1990; Östling et al., 1993). In other words, these bacteria survive starvation by expressing genes which enable the cells to enter a starvation-induced adaptation state, which is resistant not only to long-term starvation but also to a variety of physical and chemical stresses, and permits the cells to initiate outgrowth when nutrients are available (Marouga \& Kjelleberg, 1996). This response to starvation may be characterized as relatively non-active or self-contained. That is, the cells 'go with the flow (or nutrient flux)'.

In contrast to the strategy employed by copiotrophs such as E. coli, P. putida and Vibrio sp. strain S14, a different response to starvation has recently been documented for the marine ultramicrobacterium Sphingomonas sp. strain RB2256 (Eguchi et al., 1996). This marine oligotroph, which displays a remarkably constant maximum specific growth rate $\left(0 \cdot 13-0.16 \mathrm{~h}^{-1}\right)$ over a wide range of organic carbon concentrations $\left(0 \cdot 8-800 \mathrm{mg} \mathrm{C}^{-1}\right)$, is highly resistant to heat shock (to $56^{\circ} \mathrm{C}$ ), oxidative stress $\left(25 \mathrm{mM} \mathrm{H}_{2} \mathrm{O}_{2}\right)$, and ethanol stress $(20 \%, \mathrm{v} / \mathrm{v}$, ethanol) during growth, and does not gain additional starvation-acquired resistance to either $\mathrm{H}_{2} \mathrm{O}_{2}$ exposure or heat shock above that already displayed by growing cells. Starved cells do gain additional resistance to ethanol during starvation. Thus the response of Sphingomonas sp. strain RB2256 to starvation appears to be fundamentally different from that displayed by some copiotrophs.

Here we report on the starvation-stress survival of $V$. anguillarum, a major marine fish pathogen, which, we suggest, displays a response to starvation that has features different from those described above. This bacterium has been shown to survive prolonged periods of starvation-induced stress (Hoff, 1989). We have examined the starvation-stress responses of $V$. anguillarum with regard to the limiting nutrient, morphological changes during starvation and induction of stress cross-protection. It was found that the starvation-stress response of $V$. anguillarum differs from the responses exhibited by E. coli, P. putida and Vibrio sp. strain S14. First, V. anguillarum does not appear to form viable ultramicrocells as the end-point of starvation; instead, surviving cells appear to elongate into helical filaments. Second, stress cross-protection is not uniformly induced and appears slowly. Third, this cross-protection is transient. Cross-protection develops over a 24-72 h period after the initiation of starvation and then, unexpectedly, declines back to the basal, vegetative level. There is a very limited acquisition of thermal tolerance that develops during starvation. In contrast, tolerance to either $\mathrm{H}_{2} \mathrm{O}_{2}$, which develops over the first $24 \mathrm{~h}$ of starvation, or ethanol, which reaches maximum levels after $72 \mathrm{~h}$ of starvation, each results in increased cell survival by as much as several orders of magnitude followed by a decline to near the basal vegetative level. While we do not know why V. anguillarum cells are so extremely sensitive to ethanol shock at the initiation of starvation, we speculate that a protective enzyme may be washed out of the periplasm or off the outer membrane when the cells are prepared for starvation. It should be noted that cells were washed in NSS, which is the base of $3 \mathrm{M}$ broth, and were not subjected to an osmotic shock. Additionally, Eguchi et al. (1996) have reported a similar sensitivity to ethanol in washed cells of Sphingomonas sp. strain RB2256. As reported here for $V$. anguillarum, starved RB2256 cells rapidly regain resistance to ethanol during the first $24 \mathrm{~h}$ of starvation. Eguchi et al. (1996) have suggested that excreted extracellular metabolites in the culture medium are responsible for ethanol resistance.

At this stage, we cannot definitively explain why $V$. anguillarum cells elongate to form helical cells during starvation. One possibility might be that a FtsZ-like protein is inhibited in starved cells in a manner similar to that observed during the SOS response (Donachie \& Robinson, 1987). However, it is interesting to note that the appearance of helical cells during starvation and the loss of starvation-induced cross-protection coincide. We speculate that these two events are linked and may represent a physiological change in the starved $V$. anguillarum cells from a transient stage of relative metabolic shut-down, similar to established starvationsurvival responses in other non-differentiating bacteria, to a growth-like but not necessarily replicating state. Additionally, we have observed that the rate of $\left[{ }^{35} \mathrm{~S}\right]$ methionine incorporation into protein on a c.f.u. basis declines about fivefold over the first 6-24 h of starvation and then increases back to levels approaching the rates observed in exponential-phase cells by $7 \mathrm{~d}$ of starvation (see Table 1). These observations suggest that the initial response to starvation by $V$. anguillarum is a transient period of decreased metabolic activity which is followed by an active starvation response.

We also note that the c.f.u. in $V$. anguillarum cells starved for phosphorus oscillate with a periodicity of about 300-400 h. Hoff (1989) observed oscillations with a periodicity of about 8 weeks $(\sim 1350$ h) in the c.f.u. of $V$. salmonicida starved in aged sterile sea water. Hoff could not determine a reason for these oscillations. He did not observe such oscillations in a V. anguillarum culture also starved in aged sterile sea water. We hypothesize that the oscillations that we observe may be due to the cycling of phosphorus in our cultures. The c.f.u. values in cultures starved for nitrogen or carbon or multiple nutrients do not oscillate.

One question that remains open is the role of starvationstress responses in the pathogenicity of $V$. anguillarum. Clearly, both the data reported here and those published previously by Hoff (1989) demonstrate that this pathogen is able to persist in the environment for long periods of time. However, it is not known whether or how the virulence of $V$. anguillarum may be affected by starvation. Future studies will address this problem.

\section{ACKNOWLEDGEMENTS}

We thank Paul Johnson of the URI Electron Microscope Facility for providing excellent electron microscopic and photographic services. This investigation was supported by 
grants from the USDA (grant no. 93-372-079416) to D. R. N., Kinki University (Grant number 9648) to $M$. E. and the Australian Research Council to S. K.

\section{REFERENCES}

Austin, B. \& Austin, D. A. (1993). Bacterial Fish Pathogens: Diseases in Farmed and Wild Fish, 2nd edn. Chichester: Ellis Horwood.

Bolinches, J., Toranzo, A. E., Silva, A. \& Barja, J. L. (1986). Vibriosis as the main causative factor of heavy mortalities in the oyster culture industry in northwestern Spain. Bull Eur Assoc Fish Pathol 6, 1-4.

Bowser, P. R., Rosemark, R. \& Reiner, C. (1981). A preliminary report of vibriosis in cultured American lobster, Homarus americanus. J Invertebr Pathol 37, 80-85.

Donachie, W. D. \& Robinson, A. C. (1987). Cell division: parameter values and the process. In Escherichia coli and Salmonella typhimurium, Cellular and Molecular Biology, vol. 2, pp. 1578-1593. Edited by F. C. Neidhardt, J. L. Ingraham, K. B. Low, B. Magasanik, M. Schaechter \& H. E. Umbarger. Washington, DC: American Society for Microbiology.

Eguchi, M., Nishikawa, T., MacDonald, K., Cavicchioli, R., Gottschal, J. C. \& Kjelleberg, S. (1996). Responses to stress and nutrient availability by the marine ultramicrobacterium Sphingomonas sp. strain RB2256. Appl Environ Microbiol 62, 1287-1294.

Givskov, M., Eberl, L. \& Molin, S. (1994a). Responses to nutrient starvation in Pseudomonas putida KT2442: two dimensional electrophoretic analysis of starvation- and stress-induced proteins. J Bacteriol 176, 4816-4824.

Givskov, M., Eberl, L., Møller, S., Poulsen, L. K. \& Molin, S. (1994b). Responses to nutrient starvation in Pseudomonas putida KT2442: analysis of general cross-protection, cell shape, and macromolecular content. J Bacteriol 176, 7-14.

Hengge-Aronis, R. (1993). The role of $r p o S$ in early stationaryphase gene regulation in Escherichia coli K12. In Starvation in Bacteria, pp. 171-200. Edited by S. Kjelleberg. New York: Plenum Press.

Hoff, K. A. (1989). Survival of Vibrio anguillarum and Vibrio salmonicida at different salinities. Appl Environ Microbiol 55, $1775-1786$.

Holmquist, L. \& Kjelleberg, S. (1993). Changes in viability, respiratory activity and morphology of the marine Vibrio sp. strain S14 during starvation of individual nutrients and subsequent recovery. FEMS Microbiol Ecol 12, 215-224.

Jenkins, D. E., Schultz, J. E. \& Matin, A. (1988). Starvation induced cross protection against heat of $\mathrm{H}_{2} \mathrm{O}_{2}$ challenge in Escherichia coli. J Bacteriol 170, 3910-3914.

Laemmli, U. K. (1970). Cleavage of structural proteins during the assembly of the head of bacteriophage T4. Nature 227, 680-685.

Maniatis, T., Fritsch, E. F. \& Sambrook, J. (1982). Molecular Cloning: a Laboratory Manual. Cold Spring Harbor, NY: Cold Spring Harbor Laboratory.

Marden, P., Tunlid, A., Malmcrona-Friberg, K., Oldham, G. \& Kjelleberg, S. (1985). Physiological and morphological changes during short term starvation of marine bacterial isolates. Arch Microbiol 142, 326-332.

Marouga, R. \& Kjelleberg, S. (1996). Synthesis of immediate upshift (Iup) proteins during recovery of marine Vibrio sp. strain
S14 subjected to long-term carbon starvation. J Bacteriol 178, 817-822.

Matin, A. (1991). The molecular basis of carbon-starvationinduced general resistance in Escherichia coli. Mol Microbiol 5, 3-10.

Matin, A., Auger, E. A., Blum, P. H. \& Schultz, J. E. (1989). Genetic basis of starvation survival in non-differentiating bacteria. Annu Rev Microbiol 43, 293-316.

Moriarty, D. J. W. \& Bell, R. T. (1993). Bacterial growth and starvation in aquatic environments. In Starvation in Bacteria, pp. 25-53. Edited by S. Kjelleberg. New York: Plenum Press.

Morita, R. Y. (1993). Bioavailablity of energy and the starvation state. In Starvation in Bacteria, pp. 1-23. Edited by S. Kjelleberg. New York: Plenum Press.

Neidhardt, F., Block, P. L. \& Smith, D. F. (1974). Culture medium for enterobacteria. J Bacteriol 119, 736-747.

Nelson, D. R. \& Killeen, K. P. (1986). Heat shock proteins of vegetative and fruiting $M y x o c o c c u s$ xanthus cells. J Bacteriol 168 , 1100-1106.

Nelson, D. R. \& Zusman, D. R. (1983). Evidence for long-lived mRNA during fruiting body formation in Myxococcus xanthus. Proc Natl Acad Sci USA 80, 1467-1471.

Nyström, T., Albertson, N. H., Flărdh, K. \& Kjelleberg, S. (1990). Physiological and molecular adaptation to starvation and recovery from starvation by the marine Vibrio sp. S14. FEMS Microbiol Ecol 74, 129-140.

Nystrom, T. \& Kjelleberg, S. (1987). The effect of cadmium on starved heterotrophic bacteria isolated from marine waters. FEMS Microbiol Ecol 45, 143-153.

Östling, J., Holmquist, L., Flărdh, K., Svenblad, B., Jouper-Jaan, Å. \& Kjelleberg, S. (1993). Starvation and recovery of Vibrio. In Starvation in Bacteria, pp. 103-127. Edited by S. Kjelleberg. New York: Plenum Press.

Poindexter, J. S. (1981). Oligotrophy: fast and famine existence. Adv Microb Ecol 5, 63-89.

Rozak, D. B. \& Colwell, R. R. (1987). Survival strategies of bacteria in the natural environment. Microbiol Rev 51, 365-379.

Schut, F., De Vries, E. J., Gottschal, J. C., Robertson, B. R., Harder, W., Prins, R. A. \& Button, D. K. (1993). Isolation of typical marine bacteria by dilution culture: growth, maintenance, and characteristics of isolates under laboratory conditions. Appl Environ Microbiol 59, 2150-2160.

Sonenshein, A. L. (1989). Metabolic regulation of sporulation and other stationary-phase phenomena. In Regulation of Procaryotic Development: Structural and Functional Analysis of Bacterial Sporulation and Germination, pp. 109-130. Edited by I. Smith, R. A. Slepecky \& P. Setlow. Washington, DC: American Society for Microbiology.

Spector, M. P. \& Foster, J. W. (1993). Starvation-stress response (SSR) of Salmonella typhimurium. Gene expression and survival during nutrient starvation. In Starvation in Bacteria, pp. 201-224. Edited by S. Kjelleberg. New York: Plenum Press.

Zusman, D. R. (1984). Developmental program of Myxococcus xanthus. In Development and Cell Interactions, pp. 185-213. Edited by E. Rosenberg. New York: Springer.

Received 23 September 1996; revised 11 February 1997; accepted 7 March 1997. 